\title{
PROFIL KEMAMPUAN BERPIKIR GEOMETRI VAN HIELE SISWA PADA LEVEL 1 DAN LEVEL 2
}

\author{
Azwar Anwar ${ }^{1}$, Johan $^{2}$, Natal Lena ${ }^{3}$ \\ 1,2Pendidikan Matematika, Universitas Borneo Tarakan \\ ${ }^{2}$ SMP N 2 Tarakan \\ 1 $\underline{\text { azwaranwar@borneo.ac.id }}$ \\ 2johandz@gmail.com \\ 33lenanatal@gmail.com
}

\begin{abstract}
This study aims to determine the description of students' geometric abilities at level 1 and level 2 and the profile of abilities and characteristics of each level 1 and 2 based on van Hiele's theory. This type of research is descriptive research with a quantitative approach. The population of this research is class VIII SMP N 2 Tarakan. The selection of the research sample was carried out by giving the Van Hiele geometric thinking test level 1 and level 2 to 26 students. Sample selection by random sampling of 1 class. The test used in this research is the Van Hiele geometric thinking test. Each level consists of 10 multiple choice questions using 5 answer choices. For each will be given a score of 1 if correct and given 0 if wrong. Students are declared to have reached a level if they answered correctly at least 6 questions out of 10 items for each level. The data analysis technique in this study is to describe the data to find out how many students have been able to reach each level based on the Van Hiele theory. level 2. Profile at level 1 ability students are familiar with geometric shapes visually. While at level 2 students can identify geometric shapes based on their properties.
\end{abstract}

Keywords: geometry, van hiele, level 1, level 2

\begin{abstract}
Abstrak
Penelitian ini bertujuan untuk mengetahui deskripasi tentang kemampuan geometri siswa pada level 1 dan level 2 dan profil kemampuan serta karaktersitik dari setiap level 1 dan 2 berdasarkan teori van Hiele. Jenis penelitian ini ialah penelitian deskriptif dengan pendekatan kuantitatif. Populasi dari penelitian ini adalah siswa kelas VIII SMP N 2 Tarakan. Pemilihan sampel penelitian dilakukan dengan pemberian tes berpikir geometri Van Hiele level 1 dan level 2 kepada 26 siswa. Pemilihan sampel dengan random sampling terhadap 1 kelas. Tes yang digunakan dalam penelitian ini adalah tes berpikir geometri Van Hiele. Masing-masing level terdiri dari 10 soal pilihan ganda menggunakan 5 pilihan jawaban. Untuk setiap akan diberikan skor 1 jika benar dan diberikan 0 jika salah. Siswa dinyatakan mencapai suatu level jika menjawab benar minimal 6 soal dari 10 butir soal tiap levelnya. Teknik analisis data dalam penelitian ini adalah dengan deskripsi data. Berdasarkan hasil penelitian berdasarkan data deskripsi menunjukkan bahwa siswa sudah mencapai 73,07\% pada level 1 dan 46,15\% pada level 2. Profil pada kemampuan level 1 siswa sudah mengenal bangun-bangun geometri secara visual. Sedangkan pada level 2 siswa dapat mengidentifikasi bangun-bangun geometri berdasarkan sifatsifatnya.
\end{abstract}

Kata kunci: geometri, van hiele, level 1, level 2

Cara Menulis Sitasi: Anwar, A., Johan., Lena, N. (2021). Profil Kemampuan Berpikir Geometri Van Hiele Siswa Pada Level 1 dan Level 2. Mathematic Education and Aplication Journal, volume 03 no.2, halaman 2532

Pendidikan mempunyai peran penting dalam kemajuan suatu negara, ini dikarenkan dengan pendidikan dapat memajukan sumber daya manusia. Dalam dunia pendidikan tidak terlepas dari pembelajaran, terutama pembelajaran di dalam kelas. Salah satu pembelajaran yang dilakukan di kelas adalah pembelajaran matematika, di mana salah satu materinya yaitu geometri. Muhassanah, Sujadi, 
\& Riyadi (2014) menyatakan bahwa geometri memuat kompetensi dasar yaitu garis, sudut, segitiga dan segiempat, lingkaran, teorema Pythagoras, kubus, balok, prisma, limas, tabung, kerucut, bola serta menggunakannya dalam pemecahan masalah. Geometri tidak hanya mengembangkan kemampuan kognitif, peran lainnya membantu dalam pembentukan memori dari objek nyata menjadi abstrak (Asis, Alimuddin, \& Arsyad (2015). Tetapi pembelajaran geometri merupakan menjadi suatu permasalahan bagi banyak siswa, karena mereka gagal dalam mengembangkan pemahaman yang tepat tentang konsep geometri dan keterampilan pemecahan masalah geometri (Armah \& Kissi, 2019). Siswa mengganggap bahwa belajar geometri sangat sulit. Kesulitan memahami geometri terjadi karena mereka mengalami kesulitan dalam memikirkan bentuk-bentuk abstrak, menganalisis sifat-sifat benda geometris yang diamati, dan menyajikan objek geometris dalam bentuk gambar. Selain itu, siswa juga merasa kurang tertarik untuk belajar matematika. Sehingga pemahaman siswa tentang geometri masih rendah dan perlu ditingkatkan untuk memecahkan masalah (Wiska, Musdi, \& Yerizon, 2020). Hal ini sejalan dengan Widiyaningsih, Zaenuri, Dwijanto (2020) bahwa pembelajaran geometri membutuhkan kemampuan abstraksi yang relatif tinggi, meskipun tingkat berpikir geometri antar siswa berbeda-beda. Lebih lanjut guru juga menyatakan bahwa kepercayaan diri peserta didik dalam pembelajaran matematika cukup rendah, banyak siswa yang merasa tidak yakin atau yakin dengan kemampuannya.

Dalam menyampaikan suatu materi pembelajaran geometri guru perlu memperhatikan tingkat kemampuan siswa dan keadaan siswa. Kesulitan siswa dalam menyelesaikan soal geometri dikarenakan rendahnya kemampuan yang dimiliki siswa dalam memecahkan masalah (Ayuningrum, 2017). Guru dalam memberikan pengajaran perlu memperhatikan tahap perkembangan kemampuan siswa atau tingkat berpikir siswa. Solusi yang dapat digunakan dalam mengetahui tingkat berpikir siswa dalam belajar yaitu menggunakan teori Van Hiele terkhusus dalam materi geometri. Selain itu juga pentingnya guru untuk mendeskripsikan proses berpikir siswa menyelesaikan soal-soal geometri, sehingga memudahkan dalam mengetahui level berpikir siswa (Musa, 2016). Hal ini senada Abdussakir (2009), yang menyatakan bahwa pentingnya pembelajaran geometri yang seharusnya memperhatikan tingkat berpikir siswa berdasarkan teori Van Hiele, dimana teori ini memperhatikan tahap-tahap tingkat perkembangan kognitif siswa. Oleh sebab itu, perlu menjadi perhatian bagi guru ketika menyampaikan pembelajaran berdasarkan tingkat berpikir siswa (Lestariyani, Ratu, \& Yunianta, 2014). Armah \& Kissi (2019) teori van Hiele menggambarkan proses berpikir yang digunakan dalam konteks geometris. Saat seseorang maju dari satu tingkat ke tingkat berikutnya, objek pemikiran geometrisnya berubah. Di sekolah pada tingkata dasar, siswa cenderung berpindah dari level 1 ke level 2, level 2 ke level 3 dan seterusnya sampai level 5. Machisi \& Feza (2021) menyatakan bahwa teori ini yang menjelaskan bagaimana tingkat kemajuan berpikir geometris siswa memberikan wawasan tentang bagaimana guru dapat secara efektif mengajarkan bukti geometris di ruang kelas 
Usiskin (1982) menyatakan teori van Hiele mencakup deskripsi perilaku siswa di berbagai tingkatan dan memprediksi perilaku tertentu lainnya dari siswa tersebut. Tujuan dalam teori van Hiele adalah untuk menguji kemampuan teori van Hiele dalam menggambarkan dan memprediksi kinerja siswa pada tingkat sekolah menengah. Menurut teori, ada lima tingkat pemahaman dalam geometri. Tingkatan ini dijelaskan oleh van Hieles di berbagai situasi atau istilah umum dalam pembelajaran. (Armah \& Kissi, 2019) Teori diciptakan untuk memberikan dan mengembangkan pemahaman geometri. Teori van Hiele mengkategorikan siswa kemampuan belajar geometri menjadi lima tingkat pemikiran geometris yang berbeda, serta juga menawarkan model pengajaran yang dapat diterapkan guru untuk meningkatkan tingkat pemahaman siswa mereka dalam geometri. Hal ini dikarenakan guru harus mengetahui metode pengajaran yang efektif yang bertujuan untuk meningkatkan pemahaman siswa.

Berdasarkan dari beberapa penelitian mengenai teori Van Hiele yiatu penelitian dari Burger \& Shaughnessy (1986) menunjukkan bahwa siswa paling tinggi pada level 3 (deduksi informal) dan secara umum pada level 1 (visualisasi). Budiarti \& Mahendra (2016) hasil penelitian menunjukkan bahwa level tertinggi yang dicapai siswa dalam geometri Van Hiele pada level 1 (visualisasi). Penelitian Wahyudi (2016) menemukan bahwa rata-rata siswa mencapai level 1 (visualisasi) dan hanya sedikit siswa yang mencapai level 2 (analisis). Dari hasil penelitian tersebut memperlihatkan bahwa rata-rata siswa pada level 1 dan level 2 dalam berpikir geometri Van Hiele. Seperti diketahui bahwa level 1 menujukkan kemampuan siswa dalam memvisualisasi gambar atau menyebutkan sebuah bangun/gambar. Sedangkan pada level 2 yaitu kemampuan dalam mengetahui sifat-sifat bangun datar/ ruang. Armah \& Kissi (2019) berdasarkan analisis dari observasi kelas mengungkapkan bahwa perlunya menunjukkan pemahaman konseptual geometri yang baik dalam memfasilitasi pengajaran dan pembelajaran geometri yang konsisten dengan van Hiele Level 1 dan 2. Dengan begitu, dalam penelitian ini bertujuan untuk mengetahui secara mendalam tentang pemahaman geometri pada level 1 dan level 2 dan bagian mana yang paling dominan dikuasai oleh siswa, serta mengetahui karakteristik dari setiap level 1 dan 2 pada teori van Hiele.

\section{METODE}

Jenis penelitian ini ialah penelitian deskriptif dengan pendekatan kuantitatif. Jenis penelitian deskriptif kuantitatif ini digunakan untuk mendeskripsikan secara rinci tentang pemahaman berpikir geometri berdasarkan teori van Hiele siswa level 1 dan level 2. Populasi dari penelitian ini adalah siswa kelas VIII SMP N 2 Tarakan. Pemilihan sampel penelitian dilakukan dengan pemberian tes berpikir geometri Van Hiele level 1 dan level 2 kepada 26 siswa. Pemilihan sampel dengan random sampling terhadap 1 kelas. Tes yang digunakan dalam penelitian ini adalah tes berpikir geometri Van Hiele. Masing-masing level terdiri dari 10 soal pilihan ganda menggunakan 5 pilihan jawaban. Untuk 
setiap akan diberikan skor 1 jika benar dan diberikan 0 jika salah. Siswa dinyatakan lulus suatu tahapan Van Hiele mampu menjawab dengan benar minimal 6 soal dari 10 butir soal tiap levelnya. Teknik analisis data dalam penelitian ini adalah dengan deskripsi data untuk mengetahui sebesar banyak siswa yang telah mampu mencapai setiap level berdasarkan teori Van Hiele.

\section{HASIL DAN PEMBAHASAN}

Berdasarkan hasil perhitungan data yang dilakukan terhadap 26 siswa diperoleh hasil sebagai berikut.

Tabel 1. Data Deskripsi Geometri Van Hiele

\begin{tabular}{|c|c|c|}
\hline Level Geometri Van Hiele & Frekuensi & $\mathbf{\%}$ \\
\hline 1 (Visualisasi) & 19 & 73,07 \\
\hline 2 (Analisis) & 12 & 46,15 \\
\hline
\end{tabular}

Berdasarkan dari tabel tersebut terlihat bahwa hasil geometri pada setiap level yaitu terdapat 19 siswa pada level 1 atau 73,07\% dari keseluruhan siswa sedangkan terdapat 12 siswa pada level 2 atau $46,15 \%$. Sementara terdapat siswa tidak mencapai level 1 yang disebut dengan pre visualisasi yaitu sebanyak 7 siswa. Pada tahap pre visualisasi siswa terlihat bahwa mereka belum mampu atau tidak mempunyai visualisasi yang baik sehingga tidak mampu mencapai level 1. Konsep-konsep geometri masih belum mampu mereka pahami dengan baik, misalnya belum mampu membedakan antara bangun-bangun datar, kesulitan dalam memberikan nama bangun. Terkadang hal ini disebabkan oleh ketika di Sekolah Dasar belum diajarkan tentang bangun datar atau memang dari siswa sendiri belum memahami konsep-konsepnya. Padahal konsep tersebut mereka sudah pahami sebelumnya sehingga ketika naik jenjang yang lebih tinggi akan mudah untuk memahami konsep-konsep lanjutannya. Seharusnya pada jenjang SMP mereka sudah tidak kesulitan mengenai visualisasi gambar atau pada level 1. Putri, Ardhya, \& Nopriana (2019) menyatakan bahwa ada beberappa penyebab siswa belum memahami geometri, misalnya belum memahami bagaimana mengidentifikasi bangun geometri, pemahaman tentang konsep geometri masih rendah, tidak menggunakan prinsip dan dalam menggunakan pembuktian geometri. Penyebab lainnya dikarenakan, kondisi yang kurang kondusif ketika melaksanakan tes, siswa tidak diberi banyak latihan soal-soal mengenai geometri Van Hiele dan belum menerapkan tahap-tahap pembelajaran Van Hiele.

Pada level 1 terdiri dari 19 siswa dimana mereka telah mampu melewati tahap visualisasi yang mana pada level ini merupakan awal dalam berpikir Van Hiele dimana siswa mampu mengenali nama-nama bangun datar geometri berdasarkan kemampuan visualisasi mereka. Dari keseluruhan siswa yang mampu mengerjakan soal tes Van Hiele level 1 mereka mampu menggunakan visualisai dengan baik serta kemampuan mengekspresikan ide-ide matematisnya dan mengelompokkan istilah- 
istilah dalam bangun geometri (Akalili, Sunardi, Monalisa, Pambudi, \& Yudianto, 2020). Hal ini sejalan dengan Aini, Maidiyah, \& Hidayat (2018) bahwa pada level 1 siswa menggunakan visual dalam mengenali bangun geometri segiempat, mampu mengidentifikasi dan memilih bangun geometri segiempat. Sementara itu Baeti \& Murtalib (2018) menambahkan bahwa pada level 1 siswa mempunyai beberapa keterampilan, yaitu verbal, menggambar, dan logika. Keterampilan verbal meliputi mampu mengelompokkan nama-nama bangun yang mereka identifikasi, tetapi belum mampu mendefinisikan suatu bangun berdasarkan sifat-sifatnya, serta belum dapat merumuskan pernyataan yang berkaitan antar bangun-bangun tersebut. Hal ini senada dengan Wiryawan, Sukayasa, \& Awuy (2015) bahwa siswa belum mampu mengindentifikasi sifat-sifat bangun geometri. Siswa bisa saja memberikan informasi mengenai sifat-sifatnya tetapi tidak relevan dalam mengidentifikasi suatu bangun geometri. Kemudian keterampilan menggambar dimana siswa mampu menggunakan visualisasi dalam membuat atau menggambar suatu bangun dan pemberian pelabelan, namun belum mampu menggambar berdasarkan ciri atau sifat-sifatnya serta tidak mampu menggambar bangun yang berhubungan dengan bangun yang lainnya.

Hock, Tarmizi, Yunus, \& Ayub (2015) menyatakan bahwa pada level 1 merupakan tingkat yang paling rendah sehingga level ini menunjukkan pemahaman dasar dalam belajar geometri. Disisi lain, bagi siswa yang tidak mampu mencapai level 1, karakteristiknya cenderung tidak menggunakan potensi imajinasi tentang bentuk, ruang dan keterampilan belajar. Mereka tidak peduli bagaimana membayangkan bentuk dan ruang dalam belajar geometri, serta kurangnya menggunakan visualisasi sederhana dalam pemikiran geometri. Konsep seperti ini yang harus diperhatikan baik dari siswa atau guru, karena level 1 ini merupakan bagian yang paling dasar sehingga siswa tentunya sudah mampu mencapai level ini. Ketika siswa kesulitan pada level ini akan sulit untuk naik ke level selanjutnya, tentunya akan lebih sulit.

Pada level 2 terdiri dari 12 siswa telah mampu melewati tahap analisis yaitu dimana siswa sudah paham tentang sifat-sifat pada bangun geometri. Tetapi berdasarkan data tidak sampai setengahnya yang mampu mencapai level tersebut. Hal ini memperlihatkan bahwa masih rendahnya pemahaman siswa dalam mempelajari sifat-sifat bangun geometri. Pada level 2 ini siswa mampu untuk mengenal bangun berdasarkan bentuk dan sifatnya sebagaimana pendapat Aini et al., (2018) bahwa siswa mampu mengenal dan mengindentifikasi berbagai macam bangun dari sifat dan bentuknya. Serta dapat mengetahui nama-nama bangun geometri dengan menggunakan sifat-sifat utamanya saja tanpa sifat lengkapnya. Sementara itu ada beberapa keterampilan yang ada pada tahap analisis yaitu visual, verbal, menggambar dan keterampilan logika (Baeti \& Murtalib, 2018). Keterampilan visual pada tahap analisis meliputi menentukan jenis bangun geometri berdasarkan bentuknya dan sifat-sifatnya, ketika menjelaskan sifat-sifat bangun geometri dengan gambara, siswa dapat menjelaskan secara spesifik, tetapi pada level ini siswa belum mampun mengkaitkan antara satu bangun dengan bangun yang lain. Keterampilan verbal yang dimiliki oleh siswa pada level 1 (analisis) yaitu dapat mendefinisikan gambar bangun geometri berdasarkan sifat-sifat bangun tersebut. 
Keterampilan menggambar meliputi siswa dapat mengkonstruksi gambar sesuai dengan sifat-sifat bangun geometri. Keterampilan logika meliputi siswa mampu mengkonservasi bentuk gambar bangun geometri dari berbagai posisi, menyadari bahwa terdapat persamaan dari bangun geometri berdasarkan sifat-sifatnya.

Pada setiap level geometri Van Hiele tentunya siswa mempunyai kemampuan dan pengalaman sendiri sehingga adanya pertimbangan lain yang mungkin terjadi serta mempengaruhi pola pikir siswa. Mukharomah et al., (2017) menyatakan bahwa siswa yang sudah mampu mencapai level tertinggi belum tentu tingkat berpikirnya tinggi juga, begitu juga sebaliknya siswa yang hanya mencapai tingkat terendah pada level Van Hiele belum tentu tingkat berpikirnya rendah juga. Ini disebabkan oleh setiap siswa mempunyai pengalaman dan cara yang berbeda-beda dalam mengerjakan soal. Selain itu, peran dari guru juga sangat penting dalam mengurutkan dan memilih pembelajaran geometri berdasarkan tingkatan-tingakatan pemahaman berdasarkan teori Van Hiele (Falupi \& Widadah, 2016). Hal ini sejalan dengan Sejalan dengan itu, Hock et al. (2015) bahwa guru perlu memilih materi yang relevan dan melakukan eksplorasi langsung untuk mengembangkan pemikiran geometri siswa, melaksanakan proyek geometri dan mengajak siswa dalam diskusi kelas serta memberikan kesempatan untuk memperdalam pemahaman geometri siswa. Temuan dari Armah \& Kissi (2019) menunjukkan bahwa sebagian besar guru mengajarkan geometri dengan metode pembelajaran yang umun, yaitu menggunakan buku teks untuk menyajikan teorema dan bukti. Selain itu, sebagian besar latihan pembuktian yang diberikan kepada siswa tidak cukup menantang untuk memaksa siswa terlibat dalam penalaran yang efektif. Akibatnya, sebagian besar siswa tidak dapat mengingat kembali konsep geometri yang diajarkan dan juga tidak mampu menerapkan konsep secara logis.

Machisi \& Feza (2021), kontribusi penting dari teori Van Hiele untuk pengajaran dan pembelajaran bukti geometris adalah gagasan bahwa pemahaman siswa tentang konsep geometri sangat dipengaruhi oleh bagaimana guru mengajar matematika. Implikasi untuk mengajarkan bukti geometris adalah bahwa, guru matematika harus terlebih dahulu menentukan tingkat pemikiran geometris siswa saat ini untuk melihat apakah siswa siap untuk mempelajari materi geometri. Guru haru mencari solusi terlbih dahulu untuk mencapai tujuan pembelajaran geometri. Misalnya dengan menggunakan fase pengajaran dengan van Hiele, yaitu memberikan panduan tentang bagaimana merancang dan mengatur instruksi dengan cara yang meningkatkan pemahaman siswa tentang konsep geometri di tingkat manapun.

\section{KESIMPULAN}

Berdasarkan hasil pembahasan bahwa siswa pada level geometri level 1 dan level 2 mempunyai karaktersitik yang berbeda dalam menyelesaikan soal-soal geometri Van Hiele. Siswa pada level 1 kemampuan siswa yang digunakan adalah bagaiamana mereka mampu memvisualisasikan bentukbentuk bangun geometri, mengindentifikasi nama-nama bangun, dan memberikan pelabelan pada 
bangun tersebut. Sementara pada level 2 fokus pada sifat-sifat bangun-bangun geometri berdasarkan bentuknya. Namun hasil data deskripsi menunjukkan bahwa siswa belum menggunakan tingkat berpikir Van Hiele dengan baik, terutama pada level 1 yang merupakan tingkatan paling rendah, tetapi masih terdapat siswa yang belum mencapai level tersebut. Oleh karena itu peran guru sangat diperlukan dalam mengajarkan geometri berdasarkan tingkatan berpikir Van Hiele.

\section{DAFTAR PUSTAKA}

Abdussakir, (2009). Pembelajaran Geometri Sesuai Teori Van Hiele. Madrasah, Vol. 11(1), 1-13.

Aini, Z., Maidiyah, E., \& Hidayat, M. (2018). Tingkat Kemampuan Berpikir Siswa berdasarkan Teori van Hiele pada Materi Segiempat Kelas VIII SMP Negeri 1 Darussalam. Jurnal Ilmiah Mahasiswa Pendidikan Matematika, 3(2), 75-82.

Akalili, I. A., Sunardi, Monalisa, L. A., Pambudi, D. S., \& Yudianto, E. (2020). Profil Kemampuan Komunikasi Matematis Siswa Dalam Menyelesaikan Masalah Geometri Ditinjau Dari Level Van Hiele. Kadikma, 11(3), 40-45.

Armah, R. B., \& Kissi, P. S. (2019). Use of the van hiele theory in investigating teaching strategies used by college of education geometry tutors. Eurasia Journal of Mathematics, Science and Technology Education, 15(4), 1-13.

Asis, M., Alimuddin, \& Arsyad, N. (2015). Profil Kemampuan Spasial dalam Menyelesaikan Masalah Geometri Siswa yang Memiliki Kecerdasan Logis Matematis Tinggi ditinjau dari Perbedaan Gender. Jurnal Daya Matematis, 3(1), 78-87.

Ayuningrum, D. (20170. Strategi pemecahan masalah matematika siswa SMP ditinjau dari tingkat berpikir geometri van Hiele. Kreano, Jurnal Matematika Kreatif-Inovatif, 8(1), 27-34.

Baeti, N., \& Murtalib. (2018). Analisis Keterampilan Geometri Siswa dalam Memecahkan Masalah Geometri Berdasarkan Tingkat Berpikir Van Hiele Di MTS Muhammadiyah 1 Malang. Supermat Jurnal Pendidikan Matematika, 2(2), 39-50.

Budiarti \& Mahendra (2020). Analisis Pemecahan Masalah Geometri Berdasarkan Tingkat Berpikir Teori Van Hiele Dan Gender. Pi: Mathematics Education Journal, 3(1), 28-37

Burger, W. F., \& Shaughnessy, J. M. (1986). Characterizing the van Hiele levels of development in geometry. Journal for research in mathematics education, 17(1), 31-48.

Falupi, D. V., \& Widadah, S. (2016). Profil Berpikir Geometris pada Materi Bangun Datar Ditinjau dari Teori Van Hiele. Jurnal Pendidikan Matematika STKIP PGRI Sidoarjo, 4(1), 1-8.

Hock, T. T., Tarmizi, R. A., Yunus, A. S. M., \& Ayub, A. F. (2015). Understanding the Primary School Students' van Hiele Levels of Geometry Thinking in Learning Shapes and Spaces: A Qmethodology. Eurasia Journal of Mathematics, Science and Technology Education, 11(4), 793- 
802.

Lestariyani, S., Ratu, N., \& Yunianta, T.N. H. 2014. Identifikasi Tahap Berpikir Geometri Siswa SMP Negeri 2 Ambarawa Berdasarkan Teori Van Hiele. Satya Widya, Vol. 30 (2), 96-103.

Machisi, E., \& Feza, N. N. (2021). Van Hiele Theory-Based Instruction and Grade 11 Students' Geometric Proof Competencies. Contemporary Mathematics and Science Education, 2(1), 1-6.

Muhassanah, N., Sujadi, I., \& Riyadi. 2014. Analisis Keterampilan Geometri Siswa Dalam Memecahkan Masalah Geometri Berdasarkan Tingkat Berpikir Van Hiele. Jurnal Elektronik Pembelajaran Matematika, 2(1), 54-66.

Mukharomah, U. L., Hobri, \& Setiawani, S. (2017). Profil Kemampuan Berpikir Kreatif Berdasarkan Tingkat Berpikir Van Hiele Siswa Kelas VII Dalam Menyelesaikan Soal Segiempat. Kadikma, $8(3), 48-57$.

Musa, L. A. D. (2016). Level Berpikir Geometri Menurut Teori Van Hiele Berdasarkan Kemampuan Geometri dan Perbedaan Gender Siswa Kelas VII SMPN 8 Pare-Pare. Al-Khwarizmi: Jurnal Pendidikan Matematika dan Ilmu Pengetahuan Alam, 4(2), 103-116.

Putri, Ardhya, L., \& Nopriana, T. (2019). Tingkat Berpikir Geometri Van Hiele Mahasiswa Pendidikan Matematika. Prosiding Seminar Nasional Pendidikan ..., 1, 156-165.

Usiskin, Z. (1982). Van Hiele Levels and Achievement in Secondary School Geometry. The University of Chicago.

Widiyaningsih, E., Zaenuri, \& Dwijanto. (2020). Problem-Solving Ability and Self-Efficacy Based On Geometry Thinking Level in Van Hiele Learning. Unnes Journal of Mathematics Education Research, 9(2), 163-169. 4004

Wiryawan, I. M. S., Sukayasa, \& Awuy, E. (2015). Profil Tahap Berpikir van Hiele Siswa SMP Negeri 1 Balinggi dalam Belajar Segitiga dan Segiempat, Jurnal Elektronik Pendidikan Matematika, 3(1), 102-113.

Wiska, S., Musdi, E., \& Yerizon, Y. (2020). Teacher and Students Response to Learning Devices Based on van Hiele Theory. Journal of Physics: Conference Series, 1554(1). 